\title{
Correction to: Inaugural BMC Ecology and Evolution image competition: the winning images
}

Jennifer L. Harman ${ }^{1 *}$, Alison L. Cuff², Josef Settele³, Luke M. Jacobus ${ }^{4}$, David A. Liberles ${ }^{5}$ and Arne Traulsen ${ }^{6}$

\section{Correction to: BMC Ecol Evo (2021) 21:157} https://doi.org/10.1186/s12862-021-01886-7

Following the publication of the original article [1], we were notified that:

1. The description of Fig. 2 was incorrect:

- This image shows "an amphipod crustacean of the species $E$. verrucosus densely covered with an overgrown colony of parasitic ciliates. Ciliates living on weakened crustaceans are capable of forming vast colonies resembling a "fur coat"

Should read:

- This image shows "an amphipod crustacean of the species $E$. verrucosus densely covered with an overgrown colony of parasitic ciliates and unknown oomycetes or fungi. These organisms on weakened crustaceans are capable of forming vast colonies resembling a "fur coat"

2. The caption of Fig. 2 was changed from "Eulimnogammarus verrucosus, a species of crustacean endemic to the UNESCO World Heritage Site Lake Baikal, suffering from a parasitic ciliate infection. Attribution: Kseniya Vereshchagina" to "Eulimnogammarus verrucosus, a species of crustacean endemic to the UNESCO World Heritage Site
Lake Baikal, suffering from a parasitic ciliate and unknown oomycete (water mold) or fungi infection. Attribution: Kseniya Vereshchagina".

3. The affiliations of the 3rd and 4th authors had been swapped by mistake.

The original article has been corrected.

\begin{abstract}
Author details
${ }^{1}$ BMC, London, UK. ${ }^{2}$ BMC, Berlin, Germany. ${ }^{3}$ Helmholtz-Centre for Environmental Research - UFZ, Leipzig, Germany. ${ }^{4}$ Indiana University-Purdue University Columbus (IUPUC), Columbus, IN, USA. ${ }^{5}$ Temple University, Philadelphia, PA, USA. ${ }^{6}$ Max-Planck Institute for Evolutionary Biology, Schleswig-Holstein, Germany.
\end{abstract}

Published online: 09 September 2021

\section{Reference}

1. Harman JL, Cuff AL, Settele J, Jacobus LM, Liberles DA, Traulsen A. Inaugural BMC Ecology and Evolution image competition: the winning images. BMC Ecol Evo. 2021;21:157. https://doi.org/10.1186/s12862-021-01886-7.

\section{Publisher's Note}

Springer Nature remains neutral with regard to jurisdictional claims in published maps and institutional affiliations.

(c) The Author(s) 2021. Open Access This article is licensed under a Creative Commons Attribution 4.0 International License, which permits use, sharing, adaptation, distribution and reproduction in any medium or format, as long as you give appropriate credit to the original author(s) and the source, provide a link to the Creative Commons licence, and indicate if changes were made. The images or other third party material in this article are included in the article's Creative Commons licence, unless indicated otherwise in a credit line to the material. If material is not included in the article's Creative Commons licence and your intended use is not permitted by statutory regulation or exceeds the permitted use, you will need to obtain permission directly from the copyright holder. To view a copy of this licence, visit http://creativecommons.org/licenses/by/4.0/. The Creative Commons Public Domain Dedication waiver (http://creativeco mmons.org/publicdomain/zero/1.0/) applies to the data made available in this article, unless otherwise stated in a credit line to the data. 